\title{
Cadmium Transport in a Model of Neonatal Intestinal Cells Correlates to MRP1 and Not DMT1 or FPN1
}

\author{
Helena Öhrvik, ${ }^{1}$ Eva Tydén, ${ }^{1}$ Per Artursson, ${ }^{2}$ Agneta Oskarsson, ${ }^{1}$ and Jonas Tallkvist ${ }^{1}$ \\ ${ }^{1}$ Department of Biomedical Sciences and Veterinary Public Health, Swedish University of Agricultural Sciences, Box 7028, \\ 75007 Uppsala, Sweden \\ ${ }^{2}$ Department of Pharmacy, Uppsala University, Box 580, 75123 Uppsala, Sweden
}

Correspondence should be addressed to Jonas Tallkvist; jonas.tallkvist@slu.se

Received 8 November 2012; Accepted 19 December 2012

Academic Editors: D. I. Bannon, G. Borbély, K. M. Erikson, and G. O. Rankin

Copyright (C) 2013 Helena Öhrvik et al. This is an open access article distributed under the Creative Commons Attribution License, which permits unrestricted use, distribution, and reproduction in any medium, provided the original work is properly cited.

\begin{abstract}
Newborns have a higher gastrointestinal uptake of cadmium than adults. In adults, the iron transporters DMT1 and FPN1 are involved in the intestinal absorption of cadmium, while in neonates, the mechanisms for cadmium absorption are unknown. We have investigated possible cadmium transporters in the neonatal intestine by applying a model of immature human intestinal epithelial Caco-2 cells. To mimic the continuous cadmium exposure via diet in neonates, cells were allowed to differentiate for 7 days in medium containing $1 \mu \mathrm{M} \mathrm{CdCl}_{2}$. A dramatic upregulation of the MT1 gene expression followed cadmium pretreatment, indicating a high sensitivity of the immature cells to cadmium. Cadmium pretreatment increased the basolateral efflux of ${ }^{109} \mathrm{Cd}$, without causing any effects on the passive diffusion of mannitol or the transepithelial electrical resistance. The augmented transport of cadmium was correlated to an upregulation of MRP1 gene expression and increased activity of the efflux protein MRP1. No effects were observed on gene expression of the efflux proteins MRP2 and P-gp or the iron transporters DMT1, DMT1-IRE and FPN1. In conclusion, our data indicate that continuous cadmium exposure increases the absorption of the metal in immature intestinal cells and that MRP1 is involved in the intestinal cadmium absorption in newborns.
\end{abstract}

\section{Introduction}

Cadmium is a ubiquitous toxic metal that has no known biological functions but causes several adverse health effects in humans. Neonates are more sensitive to cadmium toxicity than adults, due to a higher gastrointestinal absorption [13 ] and the potential of the element to interfere in the development of the central nervous system [4]. The main source for cadmium exposure in infants is cereal and soybased infant formulas and weaning foods [3].

The intestinal absorption of cadmium in adults is generally low but increases during iron deficiency [5-9], suggesting that dietary cadmium is absorbed in the intestine by the same mechanism as non-heme iron. The major transporters responsible for the absorption of nonheme iron are the apical influx divalent metal transporter 1 (DMT1) and the basolateral efflux ferroportin 1 (FPN1) [10-12]. DMT1, the isoform DMT1-IRE (containing an iron responsive element) and FPN1 expressions are induced in human adults during iron deficiency and repressed under iron sufficient conditions $[13,14]$. In addition, studies in adult rats have demonstrated a strong correlation between cadmium absorption and duodenal expressions of DMT1 and FPN1 [15, 16]. However, in newborns the possible role of DMT1 and FPN1 in cadmium absorption has not been clarified. It has been demonstrated that the expression and localization of DMT1 and FPN1 in duodenal enterocytes is not affected by iron status, neither in suckling piglets at postnatal day 16 nor in suckling rat pups at postnatal day 10 , indicating an immature regulation of iron $[17,18]$. Thus, cadmium absorption seems to be regulated by other mechanisms at this developmental stage.

Gastrointestinal cadmium absorption may also be mediated by proteins belonging to the ATP binding cassette (ABC) superfamily of transporters [19]. Multidrug resistance associated protein 1 (MRP1) is a transporter involved in the basolateral efflux of compounds out of enterocytes into the systemic circulation [20]. Cadmium upregulates MRP1 and the protein have been demonstrated to mediate transport 
of the metal in functional yeast experiments [21, 22]. The efflux proteins MRP2 and P-glycoprotein (P-gp) located at the apical membrane of enterocytes are also upregulated by cadmium $[23,24]$ and may thus influence the bioavailability of the metal.

Repeated cadmium treatment has previously been shown to increase cadmium absorption compared to a single treatment both in vivo and in intestinal in vitro preparations of adult rats [25]. However, even though MT involvement has been suggested, the cellular mechanism for how cadmium enhances its own absorption remains to be elucidated [25]. Intestinal MT is induced by cadmium [26], but there are numerous reports concluding that the impact of MT on the intestinal cadmium absorption is of minor importance [27]. It appears that the predominant role of this cytosolic small molecular weight metal binding protein is to protect the cells from cytotoxic effects [28].

Twenty-one-day postconfluent Caco-2 cells, which are fully differentiated (mature), have been extensively used as an in vitro model of the adult human intestinal epithelium [29]. Under normal cell culture conditions, Caco-2 cells spontaneously differentiate into a phenotype that resembles polarized absorptive enterocytes [30-32]. The Caco-2 model has been widely used to investigate cadmium absorption and effects [33-38]. Mature Caco-2 cells treated with iron have reduced uptake and transport of cadmium that correlates to iron-induced decrease in DMT1 levels [37]. In concordance, a reduced cadmium uptake was demonstrated in Caco- 2 cells subjected to molecular DMT1 knock down [33]. The ABC efflux transporters MRP1, MRP2, and P-gp are present in Caco-2 cells $[39,40]$ and the expression of P-gp in these cells has been shown to be induced by long-term cadmium treatment [23].

The present study was undertaken to investigate possible transporters involved in the absorption of cadmium in the neonatal intestine and the impact of cadmium pretreatment. To mimic the continuous cadmium exposure in neonates via milk and/or formula, confluent Caco-2 cells were allowed to differentiate during 7 days (referred to as "immature Caco2 cells") in the presence and absence of cadmium. Apical to basolateral transport, studies with cadmium were performed and gene expressions of the transporters MRP1, MRP2, P-gp, DMT1, DMT1-IRE, FPN1, and of MT were quantified as well as the MRP1 activity.

\section{Materials and Methods}

2.1. Chemicals. Cadmium chloride and nitrilotriacetic acid were purchased from Sigma Aldrich. Dulbeccos' modified Eagle medium (DMEM), heat inactivated fetal calf serum, nonessential amino acids for modified Eagle medium (MEM), N-2-hydroxyethyl-piperazine- $\mathrm{N}^{\prime}$-2-ethanesulfonic acid (HEPES) buffer $1 \mathrm{M}$, nonessential amino acids (100x), and gentamycin were purchased from Invitrogen via VWR International, LLC. Apo-transferrin (tissue culture grade) was obtained from Calbiochem via VWR International, LLC. $\left[{ }^{14} \mathrm{C}\right]$-mannitol (specific activity $2.09 \mathrm{GBq} / \mathrm{mmol}$ ) was purchased from PerkinElmer and ${ }^{109} \mathrm{Cd}$ (specific activity
15.2 GBq/mg Cd ${ }^{2+}$ ) from GE Healthcare. Ultima Gold (scintillation liquid) was obtained from Chemical Instruments AB. Calcein acetoxymethyl ester (calcein AM) fluorescent dye was purchased from BD Biosciences. Hank's balanced salt solution (HBSS) and all other chemicals used, but not specified in the experiments, were of analytical grade and from VWR International, LLC.

2.2. Cell Culture and Treatment. Human intestinal Caco-2 cells were obtained from American Cell Culture Collection (Rockville, USA). The cells were cultured as previously described [41] with some minor modifications. Briefly, the Caco-2 cells were expanded in normal tissue culture flasks in DMEM supplemented with $10 \%$ fetal calf serum (Invitrogen) and $1 \%$ gentamycin $(50 \mathrm{mg} / \mathrm{mL}$, Invitrogen). The cells were seeded onto permeable polycarbonate filters at a density of $2.5 \times 10^{5}$ cells/filter support $(\varnothing 12 \mathrm{~mm}$, pore radius $0.4 \mu \mathrm{m}$, Transwell, Corning), and apical medium was changed $8 \mathrm{~h}$ after seeding to remove excess of cells and to reduce the risk of multilayer formation [42]. The Caco-2 cells were then allowed to differentiate for 7 days postconfluency. The medium was changed every second day, and the cells were examined daily by reverse phase microscopy for confluence, shape of cells, and dome formations. Cells of passage numbers 97-100 were used in the experiments.

Each cell monolayer was randomly assigned to differentiate for 7 days postconfluency in control (C) medium or medium supplemented with $1 \mu \mathrm{M}$ cadmium $\left(\mathrm{CdCl}_{2} \times 1 \mathrm{H}_{2} \mathrm{O}\right)$ (Cd). Previous investigations have demonstrated that the viability of the Caco- 2 cells at various stages of differentiation is not affected by $1 \mu \mathrm{M}$ cadmium treatment [26].

2.3. Assessment of Monolayer Integrity. The integrity of the control and cadmium pretreated monolayers was examined by determining the permeability of the hydrophilic marker ${ }^{14} \mathrm{C}$-mannitol, mainly as described [42]. Briefly, cell monolayers were rinsed with prewarmed Hank's Balanced Salt Solution pH 7.4 (HBSS) and then incubated in HBSS at $37^{\circ} \mathrm{C}$ for $20 \mathrm{~min}$. The HBSS was discarded from the apical chambers prior to transferring the filters to a fresh and prewarmed plate containing $1.5 \mathrm{~mL} 37^{\circ} \mathrm{C}$ HBSS in the basolateral chambers. HBSS $(0.5 \mathrm{~mL}, \mathrm{pH} 6.3)$ prewarmed to $37^{\circ} \mathrm{C}$ and containing $0.14 \mu \mathrm{Ci} / \mathrm{mL}^{14} \mathrm{C}$-mannitol was added to the apical chambers. The transport experiment was carried out at $37^{\circ} \mathrm{C}$ under gentle shaking $(50 \mathrm{rpm})$ for $3 \mathrm{~h}$. Every $30 \mathrm{~min}$ the filters with the monolayers were transferred to new wells containing $37^{\circ} \mathrm{C}$ HBSS and samples from both the apical and basolateral chambers were taken for subsequent determination of radioactivity by $\beta$-spectrometry (Tricarb 1900 CA, Packard). The integrity of the monolayers was also verified by measuring the net transepithelial electrical resistance (TEER) across the monolayers, as described [42]. Resistance across monolayers was measured in control and cadmium supplemented media $\left(\mathrm{pH} 7.4,37^{\circ} \mathrm{C}\right)$, and background resistance was measured across filters without cells.

2.4. ${ }^{109} \mathrm{Cd}$ Transport and Uptake. Cell monolayers, differentiated for 7 days postconfluency in control medium or 
TABLE 1: Primer sequences used for quantitative real-time PCR.

\begin{tabular}{|c|c|c|c|}
\hline Primer & Oligo sequence & NCBI GenBank Accession No. & Product size (bp) \\
\hline MRP1 forward & $5^{\prime}$-GCAAATCCAGGAGACAGCTC-3' & NM_004996 & 113 \\
\hline MRP1 reverse & $5^{\prime}$-TGATGTGCCTGAGAACGAAG-3' & & 113 \\
\hline MRP2 forward & $5^{\prime}$-CTGGTTGGGAACCTGACTGT-3' & NM_000392 & 172 \\
\hline MRP2 reverse & $5^{\prime}$-CAACAGCCACAATGTTGGTC-3' & & $1 / 2$ \\
\hline P-gp forward & $5^{\prime}$-GCTGTTAAGGAAGCCAATGC-3' & NM_000927 & \\
\hline P-gp reverse & 5'-AGCAATGGCGATTCTCTGTT-3' & & 120 \\
\hline DMT1 forward & $5^{\prime}$-CGTGGCGGATTGCAGGAGGA-3' & NM_001174126 & 124 \\
\hline DMT1 reverse & 5'-ACGCTGACCACAGCAGCCAC-3' & & \\
\hline DMT1-IRE forward & $5^{\prime}$-GCCATCAGAGCCAGTGTGTTTCT-3' & NM_001174125 & 198 \\
\hline DMT1-IRE reverse & $5^{\prime}$-TGTCAGCTTTTCAAAGATCCCACC-3' & & \\
\hline FPN1 forward & 5'-CGAGATGGATGGGTCTCCTA-3' & NM_014585 & 219 \\
\hline FPN1 reverse & $5^{\prime}$-GGCTACGTCGAAAATGTGGT-3' & & \\
\hline MT1 forward & $5^{\prime}$-GCAAATGCAAAGAGTGCAAA- ${ }^{\prime}$ & NM_005946 & 213 \\
\hline MT1 reverse & $5^{\prime}$-ATGGGTCAGGGTTGTATGGA-3' & & \\
\hline
\end{tabular}

medium supplemented with cadmium were used for uptake (from apical chamber into the cells) and transport (from apical chamber via the cells into the basolateral chamber) experiments. The experiments were performed at $37^{\circ} \mathrm{C}, \mathrm{pH}$ 7.4, in sterile filtered HBSS, buffered with $25 \mathrm{mM}$ HEPES, mainly as previously described [41]. Briefly, the monolayers were first rinsed in prewarmed HBSS and then incubated in HBSS at $37^{\circ} \mathrm{C}$ for 20 min before being transferred to new wells where fresh, $37^{\circ} \mathrm{C}$ HBSS was added to the apical $(0.5 \mathrm{~mL}, \mathrm{pH}$ 6.3) and basolateral (1.5 mL, pH 7.4, supplemented with $15 \mu \mathrm{M}$ human apo-transferrin) chambers. The apical solution was supplemented with $30 \mathrm{nM}{ }^{109} \mathrm{Cd}(1 \mu \mathrm{Ci} / \mathrm{mL})$. To determine the transport of ${ }^{109} \mathrm{Cd}$ across the monolayers $1.4 \mathrm{~mL}$, samples were taken from the basolateral chambers at $30 \mathrm{~min}$ intervals for $3 \mathrm{~h}$ and at the same time the cell monolayers were transferred to new wells containing prewarmed HBSS as described above. The radioactivity in the collected samples was measured by $\gamma$-spectrometry (Cobra, Auto-gamma, Packard). To determine the cellular uptake of ${ }^{109} \mathrm{Cd}$ from the apical chamber following the $3 \mathrm{~h}$ incubation period, the filters with the monolayers were rinsed in $4^{\circ} \mathrm{C}$ HBSS for $5 \mathrm{~min}$ and then dissolved in $1 \mathrm{~mL} 0.5 \mathrm{M} \mathrm{NaOH}$ for $48 \mathrm{~h}$, followed by $\gamma$-spectrometry of an aliquote of the lysate. In order to reduce the unstirred water layer during the transport and uptake experiments, a plate shaker was used to agitate the monolayers at a rate of $50 \mathrm{rpm}$. The experiments were reproduced two times.

2.5. Quantitative Gene Expression. Total RNA from Caco2 cells treated as described above prior to the transport experiments was isolated by the use of NucleoSpin RNA II kit containing Dnase I, according to the instructions of the manufacturer (Macherey-Nagel, Germany). The cells were rinsed with ice cold PBS prior to the addition of lysis buffer and the isolation of RNA. The integrity of the RNA was confirmed by gel electrophoresis, and quantification of the RNA was performed according to the RNAspecific Quant-iT RiboGreen protocol (Invitrogen). RNA was stored at $-70^{\circ} \mathrm{C}$ until used for quantitative gene expression analyses.
Quantification of gene expressions of the proteins presented in Table 1 was performed by one step real-time RT-PCR by applying a Rotorgene, RG 3000 instrument (Corbett Research, Australia) and QuantiTect SYBR Green RT-PCR (Qiagen) reagents, mainly according to the manufacturer's instructions. Gene expression was normalized to total RNA. Primer concentration was $0.4 \mu \mathrm{M}$, and $200 \mathrm{ng}$ total RNA was used as template. Gene-specific primers for the human genes were designed by using NCBI primer design, and all gene products were sequenced and compared against the human genome by applying the UCSC Human Genome Browser (Table 1). Triplicate $25 \mu \mathrm{L}$ volume RT-PCR reactions were used under the following PCR cycling conditions. Step 1: $50^{\circ} \mathrm{C} 30 \mathrm{~min}$; Step 2: $95^{\circ} \mathrm{C} 15 \mathrm{~min}$; Step 3: $94^{\circ} \mathrm{C} 60 \mathrm{sec}$; Step 4: $55^{\circ} \mathrm{C} 60 \mathrm{sec}$; Step 5: $68^{\circ} \mathrm{C} 45 \mathrm{~s}$; Step 6: 35 or 40 repeats of steps $3-5$; Step $7: 68^{\circ} \mathrm{C} 7 \mathrm{~min}$. In the analyses, five known concentrations of the human genes and a nontemplate control served as internal controls. Melt curve analysis was performed for each sample to check the specificity of the obtained PCR products. Relative quantification of mRNA expressions was performed as previously described [43]. Quantification of gene expressions as well as analyses of melt curves were carried out by the use of Rotorgene Software (Corbett Research, Australia).

2.6. Functional Activity: MRP-Mediated Efflux of Calcein. To measure the functional activity of MRP transporter proteins following cadmium pretreatment, an efflux assay with calcein was performed. Calcein AM is a lipophilic, nonfluorescent dye that rapidly enters cells through the plasma membrane. Once inside the cell, endogenous esterases cleave the AM ester bond releasing calcein, a hydrophilic, highly fluorescent dye that becomes trapped inside the cell. The ABC transporters MRP1 and MRP2 have been shown to transport both calcein AM and calcein. In contrast, P-gp transporter proteins efflux the nonfluorescent calcein AM, but not the fluorescent calcein from the cells into the apical chamber [44]. MRP1 transport proteins efflux both the nonfluorescent calcein AM and the fluorescent calcein from the cells across the basolateral membrane, and MRP2 transports both calcein 
AM and calcein although across the apical membrane into the apical chamber [45].

Cells were seeded onto filters and allowed to differentiate in medium supplemented with $\mathrm{Cd}$ as described above. The monolayers were washed as described above in $37^{\circ} \mathrm{C}$ HBSS, buffered with $25 \mathrm{mM}$ HEPES before loading the cells with $1.3 \mu \mathrm{M}$ calcein AM solved in $1 \%$ DMSO and added both to the apical and basolateral chambers. The loading of the cells with the permeable calcein $\mathrm{AM}$ was conducted at $7^{\circ} \mathrm{C}$, to reduce the active efflux by P-gp and MRPs of the compound, for $1 \mathrm{~h}$ in HBSS. Two quick washes in $7^{\circ} \mathrm{C}$ HBSS were performed after loading to remove excessive calcein $A M$ and then the monolayers were transferred to new wells with $37^{\circ} \mathrm{C}$ HBSS, starting the efflux study. During the $2 \mathrm{~h}$ efflux study, samples were withdrawn every $30 \mathrm{~min}$ from the basolateral chambers. At the end of the experiment, samples were withdrawn also from the apical chambers. The samples were immediately transferred to black 96 plate wells and fluorescence was measured instantly at $490 \mathrm{~nm}$ (excitation) and at $520 \mathrm{~nm}$ (emission) by a multiplate reader. During the loading and efflux experiment, a plate shaker was used to gently agitate the monolayers at a rate of $50 \mathrm{rpm}$ as described above. The functional assay of MRP-mediated calcein efflux was reproduced two times.

2.7. Statistical Analyses. The data are presented as mean \pm SEM, unless otherwise stated. The apparent permeability coefficient for mannitol was calculated as $P_{\text {app }}=$ $(\mathrm{d} Q / \mathrm{d} t)\left(1 /\left(A C_{0}\right)\right)$, where $\mathrm{d} Q / \mathrm{d} t$ is the steady state flux $(\mathrm{dpm} / \mathrm{s}), A$ is the filter area $\left(\mathrm{cm}^{2}\right)$, and $C_{0}$ is the initial concentration in the apical chamber $(\mu \mathrm{M})$. The statistical software Minitab release 15 (Minitab Inc.) was used for calculations of basic descriptive statistics and analysis of variances (ANOVA). Data were tested for homogeneity of variances by Bartlett's test. Data on cadmium transport were $\log$ transformed before statistical analysis. ANOVA was used to investigate the effects of cadmium on the dependent variables (cadmium uptake and transport, MRP activity, DMT1, DMT1-IRE, FPN1, MRP1, MRP2, P-gp, and MT1 gene expressions), followed by Tukey's test to determine differences between means. The level of significance was set at $P \leq 0.05$, two-sided.

\section{Results}

3.1. Assessment of Monolayer Integrity and Histology of the Immature Caco-2 Cells. The passive diffusion of ${ }^{14} \mathrm{C}-$ mannitol across the monolayers was linear during the $3 \mathrm{~h}$ experimental period. The apparent permeability coefficient $\left(P_{\text {app }}\right)$ for mannitol across the control monolayers was $1.15 \pm$ $0.3 \times 10^{-6} \mathrm{~cm} / \mathrm{s}$ (mean $\pm \mathrm{SD} ; n=3$ ), demonstrating that the 7 days postconfluent cells had developed a barrier. Cadmium pretreatment did not influence the apparent permeability for mannitol $(P=0.60)$. The TEER across the control monolayers was $275 \pm 18 \Omega * \mathrm{~cm}^{2}$ (mean \pm SEM; $n=6$ ). Background resistance across filters in control and cadmium supplemented media $\left(\mathrm{pH} 7.4,37^{\circ} \mathrm{C}\right)$ without cells was about
$80 \Omega * \mathrm{~cm}^{2}$. Cadmium pretreatment did not affect the TEER value for the monolayers $(P=0.70)$.

The histological examination of the sectioned immature Caco-2 monolayers did not reveal any difference between controls and cadmium pretreated cells. Dome formations were observed in all monolayers at the end of the 7 days differentiation period. The nuclei of the immature cells appeared larger and more centrally located as compared to mature cells, which have smaller nuclei with a more basal localization [31].

3.2. Transepithelial Transport and Uptake of ${ }^{109} \mathrm{Cd}$. The transport of cadmium from the apical to the basolateral chamber across the Caco-2 monolayers was linear after an initial one-hour lag phase (Figure 1(a)). At each 30 min time interval, the transport of cadmium was higher across the cadmium pretreated monolayers as compared to the controls (Figure 1(a)). The cumulative cadmium transport from the apical to the basolateral chamber was increased by $170 \%$ in cells pretreated with cadmium (Figure 1(b)). Intracellular cadmium levels in cadmium pretreated cells was reduced by approximately $20 \%$ as compared to the controls at the end of the $3 \mathrm{~h}$ incubation period (Figure $1(\mathrm{c})$ ).

3.3. Gene Expressions. The MRP1 gene expression in cells pretreated with cadmium was increased by $55 \%$ (Figure 2), whereas the MRP2 and P-gp mRNA levels were not significantly affected by cadmium pretreatment. The gene expressions of the iron transporters DMT1, DMT1-IRE, and FPN1 were not affected in the Caco-2 cells pretreated with cadmium (Figure 2). Gene expression of MT1 was increased 30 times after cadmium pretreatment (control: $1.0 \pm 0.1$; cadmium: $31.5 \pm 2.1$; mean \pm SEM; $n=3 ; P \leq 0.001)$.

3.4. Functional Activity: MRP-Mediated Efflux of Calcein. The basolateral efflux of calcein fluorescent dye was measured during two hours after one hour initial loading of the nonfluorescent dye calcein AM. Cadmium pretreatment significantly increased the efflux of calcein into the basolateral chamber (Figure 3(a)). The efflux of calcein into apical chamber was approximately four times higher than the efflux into the basolateral chamber. However, the pretreatment with cadmium did not affect the calcein efflux into the apical chamber (Figure 3(b)).

\section{Discussion}

The role of transporters in the high gastrointestinal uptake of cadmium in newborns is not fully understood $[2,17]$. In addition, the cellular mechanism behind the increased intestinal absorption of cadmium following continuous exposure than after a single dose of the metal remains to be elucidated [25]. In the present study, we have demonstrated an upregulation of the basolateral efflux protein MRP1 in immature Caco-2 cells after cadmium pretreatment, both at the gene and at the functional level. The increased MRP1 gene expression and activity was correlated to an increased cadmium transport across the basolateral membrane, indicating that MRP1 is 


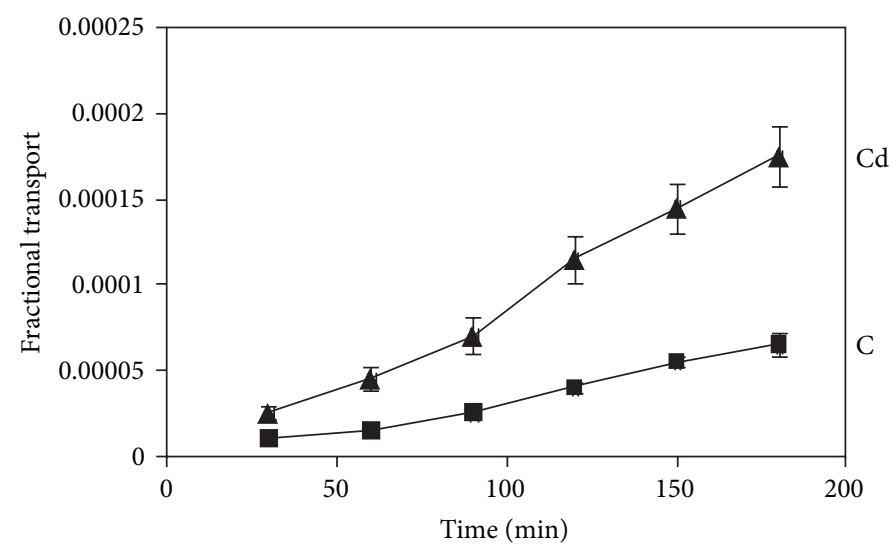

(a)

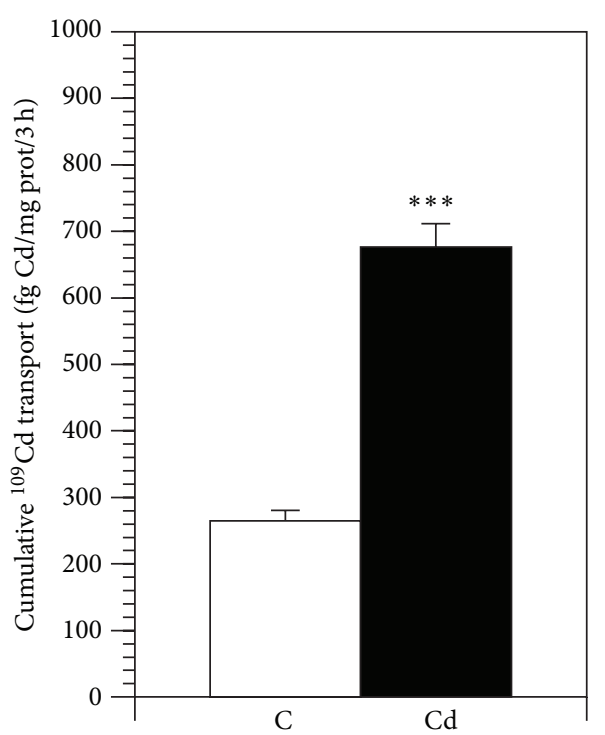

(b)

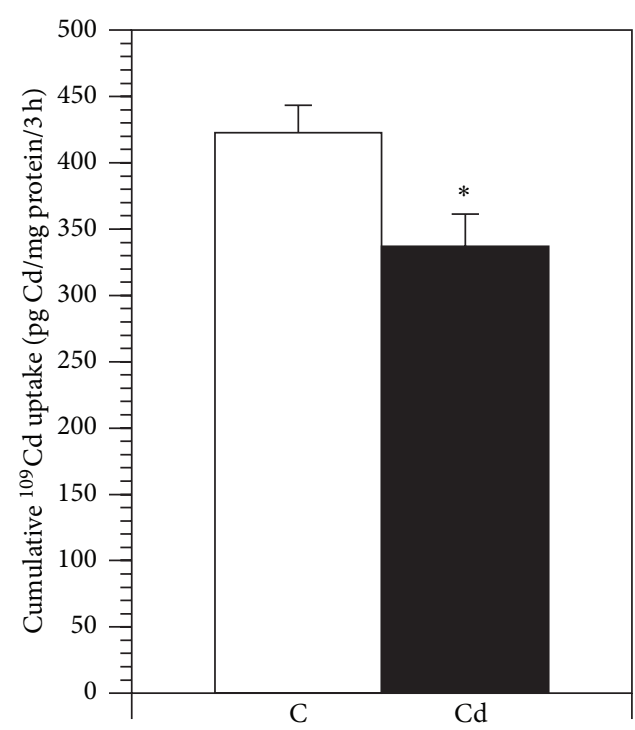

(c)

Figure 1: Fraction of ${ }^{109} \mathrm{Cd}$ transported across immature Caco-2 cells from the apical to the basolateral chamber (a). Cumulative transport of ${ }^{109} \mathrm{Cd}$ across immature Caco-2 cells (b). Apical uptake of ${ }^{109} \mathrm{Cd}$ across into immature Caco-2 cells (c). Data are presented as mean \pm SEM; $n=6$; statistical significant difference compared to control; ${ }^{*} P \leq 0.05,{ }^{* * *} P \leq 0.001$. Legends to the pretreatments: C: control; Cd: cadmium.

involved in this process. The augmented transport of the metal was not due to disrupted tight junctions as neither the passive diffusion of the paracellular marker mannitol nor the TEER was affected by cadmium. Cadmium is known to bind with high affinity to the thiol (SH) groups in GSH $[28,46]$, and it has been demonstrated in yeast that cadmiumGSH complexes can be transported by the MRP1 analogue YCF1 [21, 22]. Cadmium-GSH has also been shown to be transported by MRP1 in lung epithelial fibroblasts [47]. We suggest that cadmium, bound to $\mathrm{GSH}$, is transported by MRP1 across the basolateral membrane in the immature intestinal cells, a transport that is upregulated by cadmium pretreatment.
Our results showed a 30 -fold increase in intracellular level of MT mRNA after cadmium pretreatment of the immature Caco-2 cells. Previously, a 5-fold increase in MT has been reported after long-term cadmium treatment of mature Caco-2 cells [26], indicating that immature cells are more sensitive to cadmium treatment and therefore induces MT expression more strongly. In concordance, Cardin et al. [35], demonstrated a higher induction of MT in immature Caco-2 cells compared to mature ones. These authors also reported that cadmium treatment decreased the thiol content by $65 \%$ in Caco- 2 cells differentiated for 7 days, while no effects were observed on thiol content in mature Caco- 2 cells, indicating developmental 


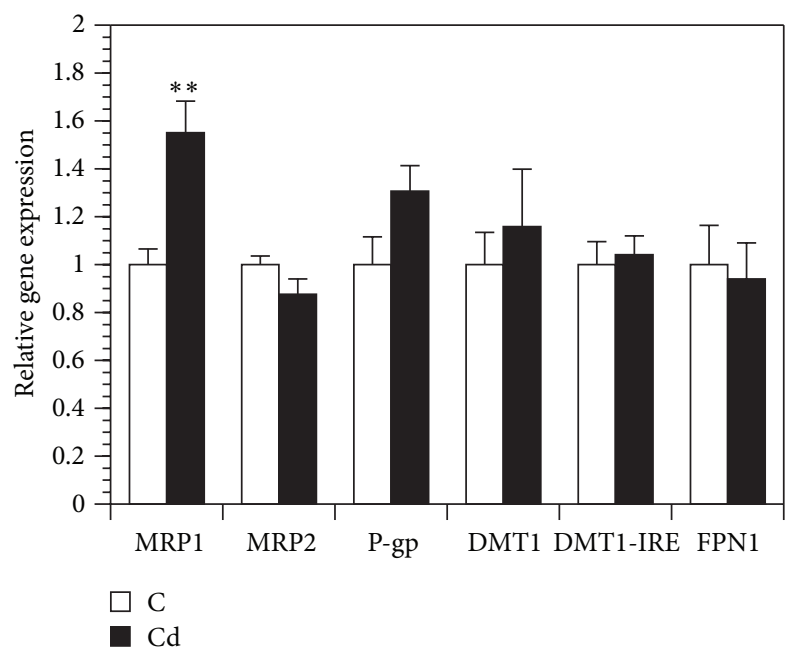

FIgure 2: Relative gene expressions of MRP1, MRP2, P-gp, DMT1, DMT1-IRE, and FPN1 in immature Caco-2 cells. Data are expressed relative to controls, set at 1 ; mean $\pm \mathrm{SEM} ; n=3$; statistical significant difference compared to control; ${ }^{*} P \leq 0.05$, ${ }^{* *} P \leq 0.01$. Legends to the pretreatments: C: control; Cd: cadmium.

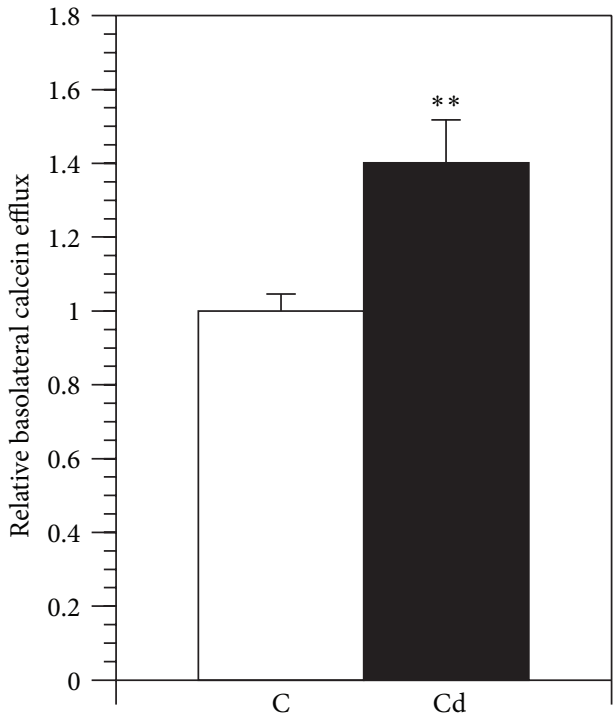

(a)

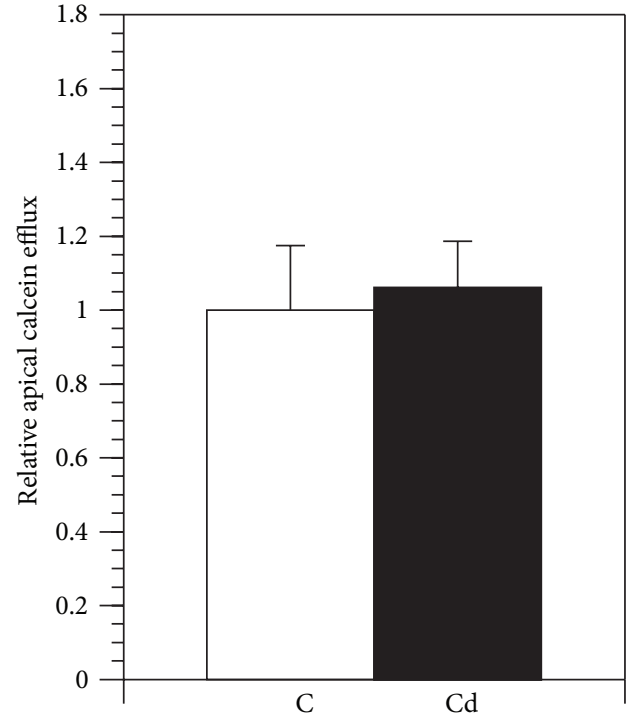

(b)

FIGURE 3: Relative basolateral (a) and apical (b) efflux of fluorescent calcein in immature Caco-2 cells. The MRP1 activity was examined by determining the cumulative level of fluorescent calcein effluxed into the basolateral chamber following two hours of incubation. Data are expressed relative to controls, set at 1 ; mean $\pm \mathrm{SD} ; n=6$; statistical significant difference compared to control; ${ }^{* *} P \leq 0.01$. Legends to the pretreatments: C: control; Cd: cadmium.

differences in the cell defense against cadmium-induced toxicity [35]. The reduced thiol content is in line with our suggestion of cadmium-induced formation of cadmiumGSH complexes, which are transported out of the cells by MRP1.

Several studies have demonstrated that the iron transporters DMT1 and FPN1, upregulated at iron deficiency and repressed at iron sufficient conditions, are involved in cadmium transport in adult mammals $[15,16]$. It has been suggested that there are ontogenic changes in the intestinal absorption and handling of iron in neonates and that iron absorption and expressions of DMT1 and FPN1 are not regulated until the time of weaning $[18,48]$. Both iron transporters are exclusively located intracellularly at mid infancy and not until weaning present at the membranes of the duodenal enterocytes in rats $[49,50]$ and in pigs [17]. In suckling piglets, neither iron nor cadmium pretreatments have resulted in any effect on expression or localization of duodenal DMT1 or FPN1 [17]. In the present study, cadmium pretreatment did not affect the gene expression of DMT1 or FPN1 in the Caco-2 cells. Thus, the increased apical to basolateral cadmium transport in cadmium pretreated cells 
cannot be explained by an increased expression of these iron transporters.

Our results demonstrate that reduced apical uptake of cadmium into cadmium pretreated Caco- 2 cells does not correlate to a reduced DMT1 or DMT1-IRE gene expression. This indicates that cadmium may be taken up by some other, nonDMT1-mediated, mechanism across the apical membrane of immature enterocytes and that cadmium pretreatment negatively affects this process. The reduced cadmium uptake after cadmium pretreatment may also in part be explained by the slightly increased gene expression of the apical efflux protein P-gp. It has been reported that long-term cadmium exposure increases $\mathrm{P}$-gp expression and activity in mature Caco- 2 cells [23]. In the present study, cadmium pretreatment did not affect gene expression or function of MRP2, which otherwise could have explained the reduced intracellular cadmium levels following exposure to the element on the apical side. The reduced cadmium uptake in the cadmiumtreated immature cells did not correlate to the transport of the element into the basolateral chamber. However, it should be pointed out that the amount of cadmium transported across the basolateral membrane of the cells only constitutes a minor fraction of the total cellular uptake. Thus, even if the intracellular cadmium levels are lower in cadmium pretreated Caco-2 monolayers, the amount of metal, for example, MRP1 is still sufficient to saturate the transporter for extracellular efflux out of the cell into the basolateral compartment.

Despite the strong MT induction, in vivo studies have demonstrated that MT only plays minimal roles in the gastrointestinal absorption of cadmium, though the retention of the metal in other tissues is MT dependent [27]. Accordingly, uptake of cadmium in the immature Caco-2 cells pretreated with cadmium was significantly reduced, indicating that MT is not involved in the retention of cadmium in neonatal enterocytes.

In summary, our results showed that cadmium pretreatment of immature Caco-2 cells upregulated MRP1 both at the gene expression and functional levels, which correlated to an increased transport of the metal across the basolateral membrane. In addition, the two iron transporters DMT1 and FPN1 were not affected by cadmium and appeared not to be involved in the intestinal transport of cadmium in immature Caco- 2 cells. In conclusion, our data indicate that continuous cadmium exposure increases the absorption of the metal in immature intestinal cells and that MRP1 conceivably is involved in the intestinal cadmium absorption in neonates.

\section{Conflict of Interests}

There is no conflict of interests.

\section{Acknowledgments}

The authors wish to thank Ph.D. Lucia Lazarova for valuable support regarding cell culture. This study was supported by the Swedish Research Council for Environment, Agricultural Sciences and Spatial Planning (FORMAS).

\section{References}

[1] H. M. Crews, L. M. Owen, N. Langford et al., "Use of the stable isotope ${ }^{106} \mathrm{Cd}$ for studying dietary cadmium absorption in humans," Toxicology Letters, vol. 112-113, pp. 201-207, 2000.

[2] G. Eklund, K. Petersson Grawé, and A. Oskarsson, "Bioavailability of cadmium from infant diets in newborn rats," Archives of Toxicology, vol. 75, no. 9, pp. 522-530, 2001.

[3] G. Eklund and A. Oskarsson, "Exposure of cadmium from infant formulas and weaning foods," Food Additives and Contaminants, vol. 16, no. 12, pp. 509-519, 1999.

[4] K. P. Grawé, J. Pickova, P. C. Dutta, and A. Oskarsson, "Fatty acid alterations in liver and milk of cadmium exposed rats and in brain of their suckling offspring," Toxicology Letters, vol. 148, no. 1-2, pp. 73-82, 2004.

[5] A. Åkesson, M. Berglund, A. Schütz, P. Bjellerup, K. Bremme, and M. Vahter, "Cadmium exposure in pregnancy and lactation in relation to iron status," American Journal of Public Health, vol. 92, no. 2, pp. 284-287, 2002.

[6] M. Berglund, A. Åkesson, B. Nermell, and M. Vahter, "Intestinal absorption of dietary cadmium in women depends on body iron stores and fiber intake," Environmental Health Perspectives, vol. 102, no. 12, pp. 1058-1066, 1994.

[7] E. Bárány, I. A. Bergdahl, L. E. Bratteby et al., "Iron status influences trace element levels in human blood and serum," Environmental Research, vol. 98, no. 2, pp. 215-223, 2005.

[8] P. R. Flanagan, J. S. McLellan, J. Haist, G. Cherian, M. J. Chamberlain, and L. S. Valberg, "Increased dietary cadmium absorption in mice and human subjects with iron deficiency," Gastroenterology, vol. 74, no. 5 I, pp. 841-846, 1978.

[9] I. M. Olsson, I. Bensryd, T. Lundh, H. Ottosson, S. Skerfving, and A. Oskarsson, "Cadmium in blood and urine-impact of sex, age, dietary intake, iron status, and former smokingassociation of renal effects," Environmental Health Perspectives, vol. 110, no. 12, pp. 1185-1190, 2002.

[10] F. Canonne-Hergaux, S. Gruenheid, P. Ponka, and P. Gros, "Cellular and subcellular localization of the Nramp2 iron transporter in the intestinal brush border and regulation by dietary iron," Blood, vol. 93, no. 12, pp. 4406-4417, 1999.

[11] A. T. McKie, P. Marciani, A. Rolfs et al., "A novel duodenal iron-regulated transporter, IREG1, implicated in the basolateral transfer of iron to the circulation," Molecular Cell, vol. 5, no. 2, pp. 299-309, 2000.

[12] N. C. Andrews and P. J. Schmidt, "Iron homeostasis," Annual Review of Physiology, vol. 69, pp. 69-85, 2007.

[13] H. Zoller, R. O. Koch, I. Theurl et al., "Expression of the duodenal iron transporters divalent-metal transporter 1 and ferroportin 1 in iron deficiency and iron overload," Gastroenterology, vol. 120, no. 6, pp. 1412-1419, 2001.

[14] J. E. Nelson, V. R. Mugford, E. Kilcourse, R. S. Wang, and K. V. Kowdley, "Relationship between gene expression of duodenal iron transporters and iron stores in hemochromatosis subjects," American Journal of Physiology, vol. 298, no. 1, pp. G57-G62, 2010.

[15] D. W. Kim, K. Y. Kim, B. S. Choi et al., "Regulation of metal transporters by dietary iron, and the relationship between body iron levels and cadmium uptake," Archives of Toxicology, vol. 81, no. 5, pp. 327-334, 2007.

[16] D. Y. Ryu, S. J. Lee, D. W. Park, B. S. Choi, C. D. Klaassen, and J. D. Park, "Dietary iron regulates intestinal cadmium absorption through iron transporters in rats," Toxicology Letters, vol. 152, no. 1, pp. 19-25, 2004. 
[17] H. Öhrvik, A. Oskarsson, T. Lundh, S. Skerfving, and J. Tallkvist, "Impact of iron status on cadmium uptake in suckling piglets," Toxicology, vol. 240, no. 1-2, pp. 15-24, 2007.

[18] W. I. Leong, C. L. Bowlus, J. Tallkvist, and B. Lönnerdal, “DMT1 and FPN1 expression during infancy: developmental regulation of iron absorption," American Journal of Physiology, vol. 285, no. 6, pp. G1153-G1161, 2003.

[19] F. Thévenod, "Catch me if you can! novel aspects of cadmium transport in mammalian cells," BioMetals, vol. 23, no. 5, pp. 857875, 2010.

[20] R. Beedholm-Ebsen, K. van de Wetering, T. Hardlei, E. Nexø, P. Borst, and S. K. Moestrup, "Identification of multidrug resistance protein 1 (MRP1/ABCC1) as a molecular gate for cellular export of cobalamin," Blood, vol. 115, no. 8, pp. 16321639, 2010.

[21] Z. S. Li, Y. P. Lu, R. G. Zhen, M. Szczypka, D. J. Thiele, and P. A. Rea, "A new pathway for vacuolar cadmium sequestration in Saccharomyces cerevisiae: YCF1-catalyzed transport of bis(glutathionato)cadmium," Proceedings of the National Academy of Sciences of the United States of America, vol. 94, no. 1, pp. 42-47, 1997.

[22] R. Tommasini, R. Evers, E. Vogt et al., “The human multidrug resistance-associated protein functionally complements the yeast cadmium resistance factor," Proceedings of the National Academy of Sciences of the United States of America, vol. 93, no. 13, pp. 6743-6748, 1996.

[23] C. Huynh-Delerme, H. Huet, L. Noël, A. Frigieri, and M. KolfClauw, "Increased functional expression of P-glycoprotein in Caco-2 TC7 cells exposed long-term to cadmium," Toxicology In Vitro, vol. 19, no. 4, pp. 439-447, 2005.

[24] S. A. Terlouw, C. Graeff, P. H. E. Smeets et al., "Short and long term influences of heavy metals on anionic drug efflux from renal proximal tubule," Journal of Pharmacology and Experimental Therapeutics, vol. 301, no. 2, pp. 578-585, 2002.

[25] K. H. Flaig, K. Schümann, and B. Elsenhans, "Jejunal transfer rates of 109 cadmium chloride increase in rats in vitro and in vivo after oral pretreatment with cadmium or zinc chloride," Toxicology, vol. 183, no. 1-3, pp. 199-209, 2003.

[26] A. Blais, S. Lecoeur, G. Milhaud, D. Tomé, and M. Kolf-Clauw, "Cadmium uptake and transepithelial transport in control and long-term exposed Caco-2 cells: the role of metallothionein," Toxicology and Applied Pharmacology, vol. 160, no. 1, pp. 76-85, 1999.

[27] C. D. Klaassen, J. Liu, and B. A. Diwan, "Metallothionein protection of cadmium toxicity," Toxicology and Applied Pharmacology, vol. 238, no. 3, pp. 215-220, 2009.

[28] C. D. Klaassen, J. Liu, and S. Choudhuri, "Metallothionein: an intracellular protein to protect against cadmium toxicity," Annual Review of Pharmacology and Toxicology, vol. 39, pp. 267294, 1999.

[29] P. Artursson, K. Palm, and K. Luthman, "Caco-2 monolayers in experimental and theoretical predictions of drug transport," Advanced Drug Delivery Reviews, vol. 46, no. 1-3, pp. 27-43, 2001.

[30] P. Artursson, "Epithelial transport of drugs in cell culture. I: a model for studying the passive diffusion of drugs over intestinal absorptive (Caco-2) cells," Journal of Pharmaceutical Sciences, vol. 79, no. 6, pp. 476-482, 1990.

[31] I. Chantret, A. Barbat, E. Dussaulx, M. G. Brattain, and A. Zweibaum, "Epithelial polarity, villin expression, and enterocytic differentiation of cultured human colon carcinoma cells: a survey of twenty cell lines," Cancer Research, vol. 48, no. 7, pp. 1936-1942, 1988.

[32] M. Pinto, S. Robine Leon, and M. D. Appay, "Enterocyte-like differentiation and polarization of the human colon carcinoma cell line Caco-2 in culture," Biology of the Cell, vol. 47, no. 3, pp. 323-330, 1983.

[33] D. I. Bannon, R. Abounader, P. S. J. Lees, and J. P. Bressler, "Effect of DMT1 knockdown on iron, cadmium, and lead uptake in Caco-2 cells," American Journal of Physiology, vol. 284, no. 1, pp. C44-C50, 2003.

[34] M. Boveri, P. Pazos, A. Gennari, J. Casado, T. Hartung, and P. Prieto, "Comparison of the sensitivity of different toxicological endpoints in Caco-2 cells after cadmium chloride treatment," Archives of Toxicology, vol. 78, no. 4, pp. 201-206, 2004.

[35] G. B. Cardin, M. Mantha, and C. Jumarie, "Resistance to cadmium as a function of Caco- 2 cell differentiation: role of reactive oxygen species in cadmium- but not zinc-induced adaptation mechanisms," BioMetals, vol. 22, no. 5, pp. 753-769, 2009.

[36] C. Jumarie, P. G. C. Campbell, A. Berteloot, M. Houde, and F. Denizeau, "Caco-2 cell line used as an in vitro model to study cadmium accumulation in intestinal epithelial cells," Journal of Membrane Biology, vol. 158, no. 1, pp. 31-48, 1997.

[37] J. Tallkvist, C. L. Bowlus, and B. Lönnerdal, "DMT1 gene expression and cadmium absorption in human absorptive enterocytes," Toxicology Letters, vol. 122, no. 2, pp. 171-177, 2001.

[38] P. Carrière, M. Mantha, S. Champagne-Paradis, and C. Jumarie, "Characterization of basolateral to apical transepithelial transport of cadmium in intestinal TC7 cell monolayers," BioMetals, vol. 24, no. 5, pp. 857-874, 2011.

[39] G. Englund, F. Rorsman, A. Rönnblom et al., "Regional levels of drug transporters along the human intestinal tract: coexpression of ABC and SLC transporters and comparison with Caco-2 cells," European Journal of Pharmaceutical Sciences, vol. 29, no. 3-4, pp. 269-277, 2006.

[40] H. M. Prime-Chapman, R. A. Fearn, A. E. Cooper, V. Moore, and B. H. Hirst, "Differential multidrug resistance-associated protein 1 through 6 isoform expression and function in human intestinal epithelial Caco-2 cells," Journal of Pharmacology and Experimental Therapeutics, vol. 311, no. 2, pp. 476-484, 2004.

[41] J. Tallkvist and H. Tjälve, "Transport of nickel across monolayers of human intestinal Caco-2 cells," Toxicology and Applied Pharmacology, vol. 151, no. 1, pp. 117-122, 1998.

[42] I. Hubatsch, E. G. E. Ragnarsson, and P. Artursson, "Determination of drug permeability and prediction of drug absorption in Caco-2 monolayers," Nature Protocols, vol. 2, no. 9, pp. 21112119, 2007.

[43] K. J. Livak and T. D. Schmittgen, "Analysis of relative gene expression data using real-time quantitative PCR and the 2$\Delta \Delta$ CT method," Methods, vol. 25, no. 4, pp. 402-408, 2001.

[44] L. Homolya, Z. Hollo, U. A. Germann, I. Pastan, M. M. Gottesman, and B. Sarkadi, "Fluorescent cellular indicators are extruded by the multidrug resistance protein," The Journal of Biological Chemistry, vol. 268, no. 29, pp. 21493-21496, 1993.

[45] N. Feller, H. J. Broxterman, D. C. R. Wahrer, and H. M. Pinedo, "ATP-dependent efflux of calcein by the multidrug resistance protein (MRP): no inhibition by intracellular glutathione depletion," FEBS Letters, vol. 368, no. 2, pp. 385-388, 1995.

[46] M. S. Díaz-Cruz, J. Mendieta, R. Tauler, and M. Esteban, "Cadmium-binding properties of glutathione: a chemometrical analysis of voltammetric data," Journal of Inorganic Biochemistry, vol. 66, no. 1, pp. 29-36, 1997. 
[47] S. H. Oh, S. Y. Lee, C. H. Choi, S. H. Lee, and S. C. Lim, "Cadmium adaptation is regulated by multidrug resistanceassociated protein-mediated Akt pathway and metallothionein induction," Archives of Pharmacal Research, vol. 32, no. 6, pp. 883-891, 2009.

[48] M. Domellöf, R. J. Cohen, K. G. Dewey, O. Hernell, L. L. Rivera, and B. Lönnerdal, "Iron supplementation of breast-fed Honduran and Swedish infants from 4 to 9 months of age," Journal of Pediatrics, vol. 138, no. 5, pp. 679-687, 2001.

[49] S. L. Kelleher and B. Lönnerdal, "Zinc supplementation reduces iron absorption through age-dependent changes in small intestine iron transporter expression in suckling rat pups," Journal of Nutrition, vol. 136, no. 5, pp. 1185-1191, 2006.

[50] V. Lopez, Y. A. Suzuki, and B. Lönnerdal, "Ontogenic changes in lactoferrin receptor and DMT1 in mouse small intestine: implications for iron absorption during early life," Biochemistry and Cell Biology, vol. 84, no. 3, pp. 337-344, 2006. 

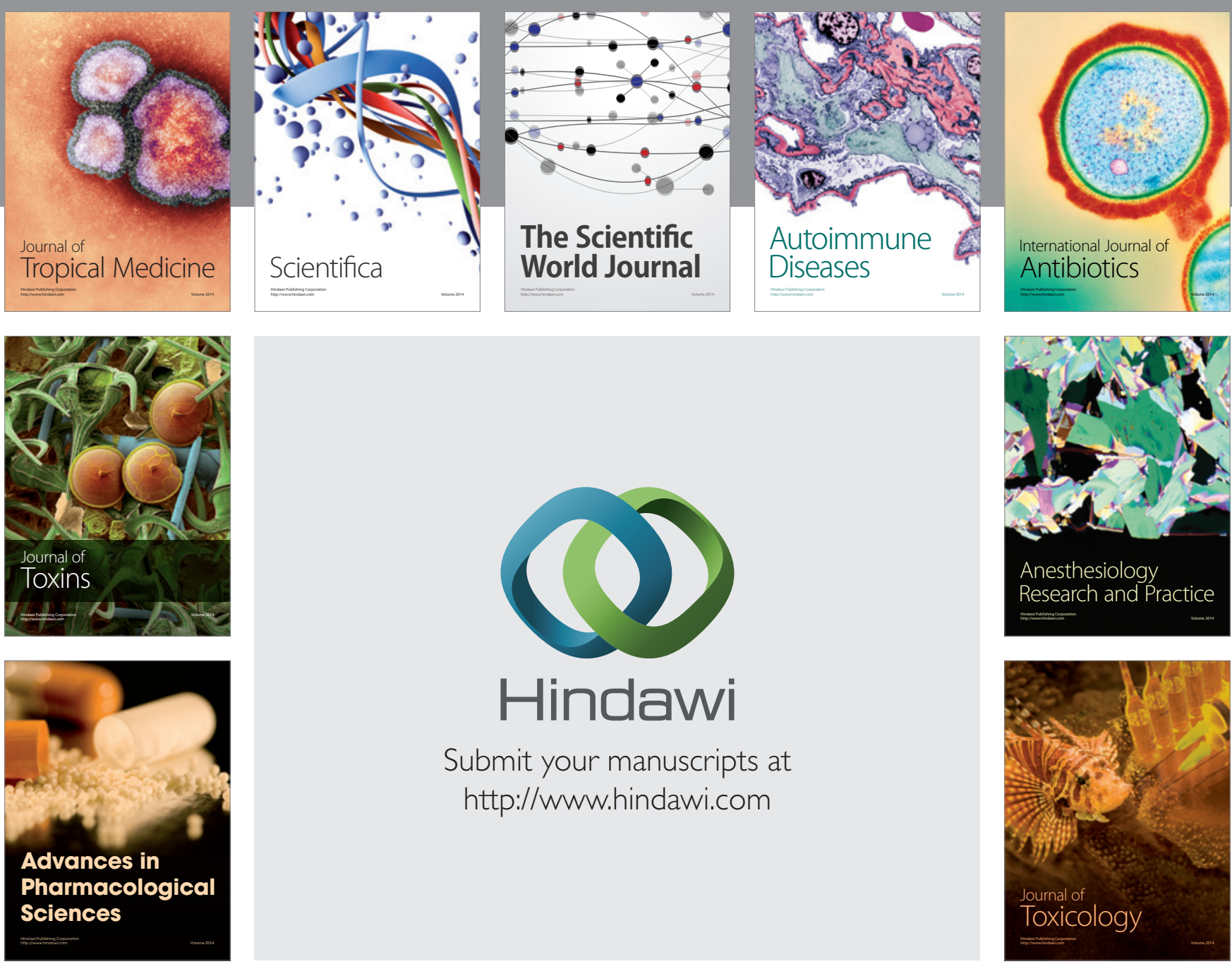

\section{Hindawi}

Submit your manuscripts at

http://www.hindawi.com
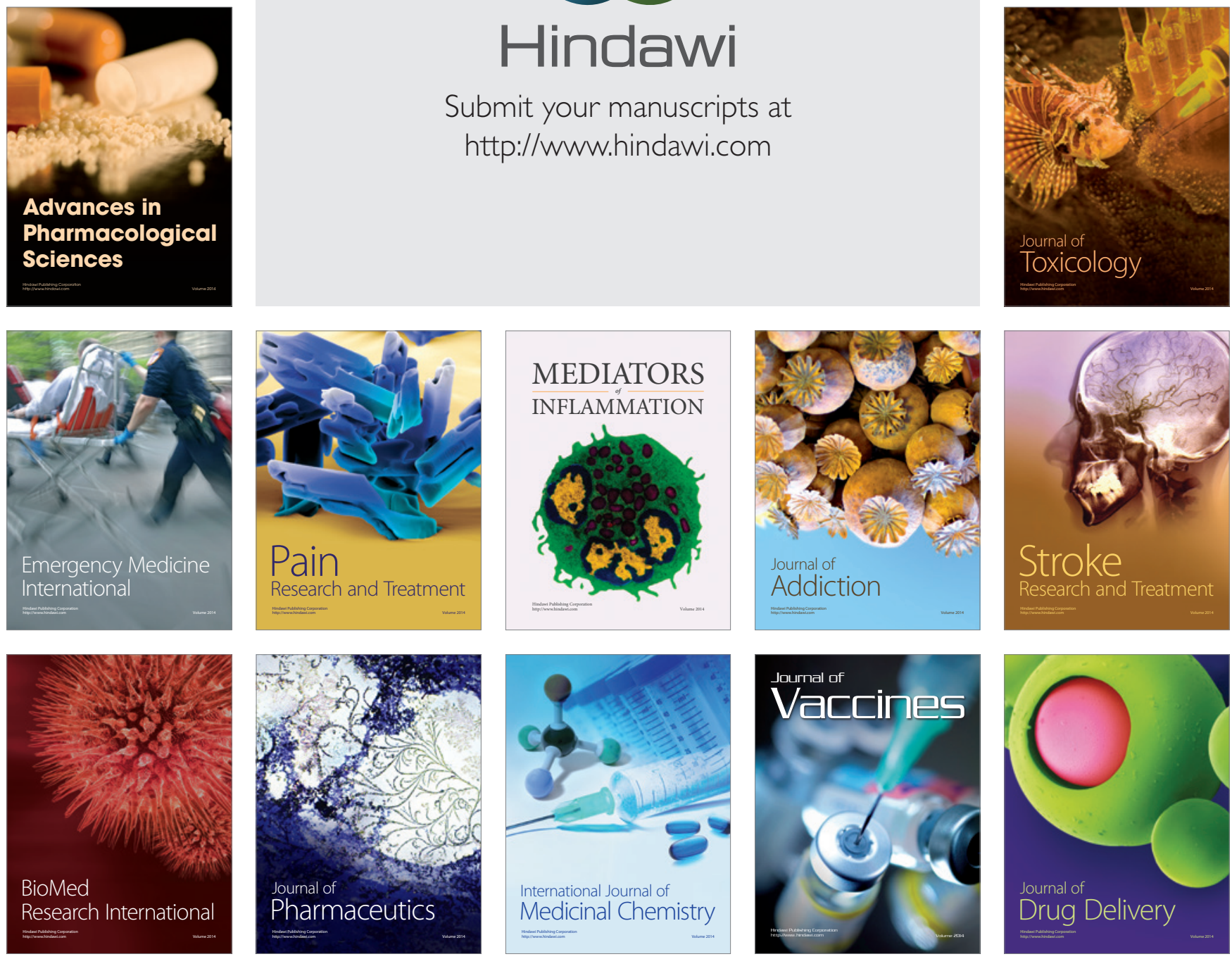